\title{
The Effects of some Processing Variables on the Quality of Canned Pigeonpeas
}

\author{
F. Sánchez Nieva, M. A. González, and J. R. Benero ${ }^{1}$
}

\section{INTRODUCTION}

Although pigeonpeas (Cajan cajan $L$.) have been commercially canned in Puerto Rico and other Caribbean countries for many years, limited information only is available on processing methods. In commercial canning operations pigeonpeas are handled and processed like peas (Pisum sativum). The commercial canned product is normally characterized by having a dark brine of high turbidity. Sánchez et al. $(1)^{2}$ developed an improved process for canning pigeonpeas by the use of which it is possible to obtain a product with an almost colorless brine, free of suspended solids. The essential step of this process consists of inactivating the peroxidases of the peas in the pod stage by steaming the pods before shelling. This improved process not only prevents discoloration of the brine, but also improves the overall quality of the canned product.

During the development of this new process the authors observed that some other factors besides enzyme inactivation before shelling were affecting the color and turbidity of the brine of the canned product. The examination of many samples of pigeonpeas canned by the new process showed that darkening of the brine could not be attributed always to incomplete inactivation of the enzyme system before shelling. It was also observed that the color and turbidity of the brine of canned samples from the same lot showed a great variation, even when the peroxidases had been completely inactivated.

A critical study of the possible causes of the unexpected variation in the color and turbidity of the brine clearly suggested that some specific processing variables may be responsible for these changes, namely the length and temperature of postharvest storage, the blanching treatment, the use of metals other than stainless steel in the contact surfaces of the processing equipment, the type of cans used, the length of the holding-time before retorting, the cooling of the cans, and the storage of the canned product before analysis and inspection.

1 Technical Director, Assistant Chemical Engineer, and Assistant Chemist, respectively of the Food Technology Laboratory of the Agricultural Experiment Station, University of Puerto Rico, Rio Piedras, P.R. The authors wish to express their gratitude to all those members of the staff of the Food Technology Laboratory who assisted in the development of this work by analyzing samples or participating in the taste tests.

2 Italic numbers in parentheses refer to Literature Cited, p. 258. 


\section{PROCESSING METHODS USED}

Pigeonpeas of the Kaki and Saragateado varieties were processed in a pilot line with a capacity of 500 pounds of pods per hour. Only one variety was used for each set of experiments. The pods were steamed to inactivate the enzyme system as described by Sánchez et al. (1) unless otherwise indicated. The steamed pods were shelled in a huller and the shelled pigeonpeas flumed from the huller to a rod-reel washer. The small pigeonpeas going through the spacings of the washer were discarded, only the primary discharge from this machine being used for processing. The peas were transferred in trays to a picking-belt where defective peas were removed. From the picking-belt a rubber-cleat elevator moved the peas to a rodreel washer which discharged directly into the blancher. The pigeonpeas were blanched in water at $185^{\circ} \mathrm{F}$. for 5 minutes in a rotary blancher equipped with dual temperature controls to maintain uniform temperature throughout. The blanched peas were cooled in a rotary rod-reel washer and transferred to a second picking-belt for a final selection. The peas were packed in plain tin cans with C-enameled ends or in fully enameled cans. A fill-in weight of 11.5 ounces was always used. Hot 2-percent brine at $200^{\circ} \mathrm{F}$. was added, or hot water and one 70-grain salt tablet instead. The cans were immediately closed and processed at $240^{\circ} \mathrm{F}$. for 35 minutes and cooled in the retort; they were air-dried and stored at room temperature $\left(85^{\circ} \mathrm{F}\right.$.) until used.

\section{ANALYTICAL METHODS USED}

\section{LABORATORY PROCEDURES}

Color of brine and pigeonpeas was measured with a Hunter color and color-difference meter. For measuring the color of the brine, $30 \mathrm{ml}$. of brine taken from a can immediately after opening were placed in a Hellige No. 8010-50 cup, 50-mm. viewing depth, and the color was measured by transmittance with the meter calibrated for $T=99, a=0, b=0$. Color values were calculated from the equation. Color of brine $=\sqrt{T^{2}+a^{2}+b^{2}}$, where $T, a$, and $b$ are the values read directly from the meter scales. Low values for the color index indicate dark-colored and high values lightcolored brines. The pigeonpeas after draining from the can were placed in the same type of Hellige cup and their color was measured with the meter adjusted for reflectance measurements against a standard color-plate with values of $R_{d}=9.7, a=-0.1, b+19.6$. A color index was obtained from the color equation, $\sqrt{\mathrm{R}_{d}{ }^{2}+a^{2}+b^{2}}$. Since most samples had almost the same color, it was felt unnecessary to calculate color difference between the sample and the standard.

'Turbidity of the brine was measured in the Klett-Summerson colorimeter 
using a No. 47 blue filter. A sample of the brine was taken immediately after opening the can and diluted 1:1 with distilled water. A 10-ml. sample was placed in the tube and the transmittance read. Turbidity measurements are expressed in Klett-Summerson scale units. High values for turbidity indicate less transparent brines, and low values brines of low turbidity.

Drained weight was determined by the standard USDA procedure (2) by draining for 2 minutes in a sieve 8 inches in diameter containing 8 meshes to the inch. Alcohol-insoluble solids were determined by the AOAC method (3). The tenderness or hardness of pigeonpeas treated with $\mathrm{CaCl}_{2}$ solutions was measured as follows: A Luer syringe was clamped in a vertical position with the plunger downwards. The syringe was connected to a pressure-controlling valve through which air at any desired pressure could be admitted to the syringe. A low-reading air gage was connected to the system. Individual peas were placed under the plunger of the syringe and air pressure applied until the peas were deformed and the cotyledons lost their shape. The pressure at which the cotyledons broke was recorded and used as a measure of tenderness or hardness.

\section{ORGANOLEPTIC TESTS}

For quality appraisal based only on the color and turbidity of the brine the cans were opened carefully so as not to disturb the brine. Tasters were required to base their judgment on the appearance of the product in the can with respect to the color and turbidity of the brine and the appearance of the peas under the brine. Rating of the drained peas was carried out under daylight.

For flavor evaluation the drained pigeonpeas were served to tasters in white porcelain dishes in an air-conditioned booth under red light. Tasters were required to rate the product on a 5-point scale with respect to flavor, intensity of off-flavors, and tenderness.

\section{GRADE DETERMINATION}

Score and grade were determined according to the standards issued by the Commonwealth of Puerto Rico Department of Agriculture.

\section{RESULTS}

\section{EFFECT OF COLD STORAGE OF PODS ON QUALITY \\ OF CANNED PRODUCT}

In the commercial processing of the pigeonpeas the processing plants may receive more peas than they can handle during the peak of the crop. The surplus material is usually piled up in jute bags for 2 or 3 days before processing. During storage at room temperature the peas heat to such an extent that the authors have measured temperatures in excess of $100^{\circ} \mathrm{F}$. 
inside the bags. This results in the discoloration of the peas and in the development of off-flavors. In the course of our work we were faced with the old problem of receiving at the Laboratory more pigeonpeas than we could process in a day. It was felt important to investigate whether they could be kept in good condition for processing later on if the pods were stored at $45^{\circ} \mathrm{F}$. as soon as received.

The pods were packed into 4/5-bushel wooden crates and stored in a walk-in refrigerator at $45^{\circ} \mathrm{F}$. Lots of suitable size for processing were removed from the refrigerator the next morning after being received, and processed. Other lots from the same truckload were processed at regular intervals later on. Processing data were carefully recorded to determine whether cold storage had any effect on the shelled-out percentage obtained and on the efficiency of the processing line. The processing data obtained when the pigeonpeas were processed after being stored at $45^{\circ} \mathrm{F}$. for half a

TABLE 1.-Effect of storing fresh pigeonpeas in the pods at $45^{\circ} \mathrm{F}$. for different periods on the performance of the processing line

\begin{tabular}{l|c|c|c}
\hline \multirow{2}{*}{ Item } & \multicolumn{2}{|c}{ Results after storage at $45^{\circ}$ F. for- } \\
\cline { 2 - 3 } & 0.5 day & s days & 9 days \\
\hline Primary peas, percentage of pods & 41.69 & 42.0 & 39.82 \\
Secondary peas, percentage of pods & 2.36 & 2.31 & 2.42 \\
Shelled-out percentage & 44.05 & 44.3 & 42.24 \\
No.2 cans produced per 100 lb. processed & 52.6 & 52.5 & 50.0 \\
\hline
\end{tabular}

day, for 5 days, and for 9 days are given in table 1 . The data show that the cold storage of the pods had no effect on the efficiency of the processing line. The shell-out percentage of peas was about the same for all three runs. The lower shell-out percentage from the last lot processed after storage for 9 days is not significant and is within the normal variation to be expected. The number of cans theoretically produced was similar for the three runs. In calculating the yield of cans per 100 pounds of pods processed it was necessary to base the calculations on the yield of pigeonpeas obtained after shelling and picking, and not on the actual number of cans produced. Uncontrolled losses at the filling station introduced an appreciable error in figures based on the number of cans produced.

It was observed that the pods showed a tendency during cold storage to become tougher, which might make shelling more difficult. However, since the pods were steamed before shelling to inactivate the enzyme system, this treatment reduced the toughness to a point where the huller operated as efficiently as with fresh pods.

Examination of the canned product showed that the storage of the pods 
at $45^{\circ} \mathrm{F}$. for 9 days had no effect on the quality. When the canned pigeonpeas were graded according to the standards of the Commonwealth Department of Agriculture it classified as an A-grade product. Similarly, cold storage had no appreciable effect on the color or turbidity of the brine, as can be seen from the data in table 2. Organoleptic appraisal of the product also indicated that no major change in organoleptic properties took place during storage. Results from the organoleptic tests are given in table 3. No

TABLE 2.-Effect of storing fresh green pigeonpeas in the pods at $45^{\circ} \mathrm{F}$. for different periods on the quality of the canned product

\begin{tabular}{|c|c|c|c|}
\hline \multirow{2}{*}{ Characteristic } & \multicolumn{3}{|c|}{ Results after storage at $45^{\circ} \mathrm{F}$. for -} \\
\hline & 0.5 day & 5 days & 9 days \\
\hline Liquor-classification score & 14.0 & 14.0 & 14.0 \\
\hline Color-of-peas score & 22.4 & 22.3 & 23.1 \\
\hline Defect score & 29.5 & 29.4 & 29.6 \\
\hline Character score & 29.6 & 29.2 & 29.6 \\
\hline General classification grade & $\mathbf{A}$ & $\mathbf{A}$ & $\mathbf{A}$ \\
\hline Turbidity of brine & 297 & 298 & 330 \\
\hline Color of brine & 36.0 & 35.0 & 33.2 \\
\hline
\end{tabular}

TABLE 3.-Effect of storing fresh pigeonpeas in the pods at $45^{\circ} \mathrm{F}$. for different periods on the organoleptic properties of the canned pigeonpeas

\begin{tabular}{l|c|c|c}
\hline \multirow{2}{*}{ Characteristic } & \multicolumn{2}{|c|}{ Rank on 5-point scale after number of days in storage indicated } \\
\cline { 2 - 4 } & 0 & 5 & 9 \\
\hline Appearance of brine in the can & 3.3 & 3.1 & 2.1 \\
General appearance of product & 2.7 & 2.5 & 2 \\
in the can & 2.5 & 3.1 & 3.3 \\
Appearance of drained peas & & \\
\hline
\end{tabular}

significant difference could be established in flavor, quality, tenderness, or intensity of off-flavors among samples from the lots processed after cold storage for the times indicated.

Cold storage of the pods has been shown to be feasible for as long as 9 days. Since no changes in shell-out percentage or in the quality of the canned product could be found to have taken place when the pods were stored at $45^{\circ} \mathrm{F}$. for 9 days, cold storage of the pods should be used to avoid the heavy losses usually encountered by canners from the processing of pods which have been stored for several days at room temperature. Cold storage of the pods will assure the production of a high-quality pack throughout the season. 


\section{EFFECT OF THE BLANCHING TREATMENT ON THE QUALITY OF CANNED PIGEONPE.LS}

Sánchez et al. (1) showed that when pigeonpeas are processed by steaming the pods before shelling, a postwater blanching treatment is essential to obtain a canned product with a colorless brine. Since the enzyme system has been inactivated prior to the blanching treatment, blanching can be thought of as improving the color and turbidity of the brine by removing or rendering soluble some color-forming constituent which may later react, possibly with iron or some other metallic ion, to form dark-colored compounds. Evidence to support this theory was obtained from the following experiments:

Fresh pigeonpeas were boiled in distilled water in a glass beaker. They were drained and a colorless extract was obtained. When a few drops of $\mathrm{FeCl}_{3}$ were added a bluish-black color developed which closely resembled

TABLE 4.-Efect of length of blanching period on the drained weight and color and turbidily of brine of canned pigeonpeas

\begin{tabular}{|c|c|c|c|c|}
\hline Factor determined & \multicolumn{4}{|c|}{ Results when blanching at $180^{\circ} \mathrm{F}$. } \\
\hline Length of blanching...........minutes & 5 & 7 & 9 & 11 \\
\hline Fill-in weight $\ldots \ldots \ldots \ldots \ldots$ ounces & 11.75 & 11.75 & 11.75 & 11.75 \\
\hline Drained weight $\ldots \ldots \ldots \ldots \ldots$ do. & 12.8 & 13.1 & 12.9 & 12.8 \\
\hline Turbidity of brine & 170 & 139 & 146 & 112 \\
\hline Color of brine & 42.6 & 50.5 & 50.2 & 56.5 \\
\hline
\end{tabular}

that of discolored brine. It is reasonable to assume that, if the color-forming substances can be water-extracted, the length of the blanching treatment will have a direct effect on the color and turbidity of the brine.

The data given in table 4 show that when pigeonpeas were blanched at $180^{\circ} \mathrm{F}$. the color and turbidity of the brine decreased as the length of the blanching treatment was increased. It should be noted that the color index has a high value for light-color brines and vice versa, the darker the brine the lower the value of the color index. It can be seen from the data that when the length of the blanching treatment was increased from 5 to $11 \mathrm{~min}-$ utes, a reduction of 58 units in the turbidity of the brine took place. A lighter color was likewise obtained.

The data in table 4 also show the effect of the length of the blanching treatment on the drained weight. At $180^{\circ} \mathrm{F}$. no increase in drained weight was obtained when the blanching treatment was extended from 5 to 11 minutes. The blanching temperature was thus found to have little if any effect on the drained weight. Table 5 shows that blanching treatments varying in length from 5 to 7 minutes at temperatures of $180^{\circ} \mathrm{F}$., $190^{\circ} \mathrm{F}$., $195^{\circ} \mathrm{F}$., 
and $200^{\circ} \mathrm{F}$., had little effect on the drained weight. It should be noted that the blanching treatment had little or no effect in preventing or increasing the rupturing of the epicarp of green and yellow peas. The data in table 5 clearly indicate that rupturing of the epicarp is related to maturity rather than to the blanching treatment. On counting the peas in the can, it was observed that fully developed green peas showed less tendency to crack than fully mature yellow peas. The percentage of cracks in the green peas was around 30 of the total number in the can, while more than 85 percent of the mature yellow peas showed cracks.

As has already been pointed out the length of the blanching treatment affects the color and turbidity of the brine, possibly by rendering colorforming substances soluble. Then it is to be expected that the rate of flow of make-up water through the blancher should also have a direct effect on

TABLE 5.-Effect of blanching treatment on drained weight and percentage of split pigeonpeas

\begin{tabular}{l|c|c|c|c}
\hline \multirow{2}{*}{ Blanching treatment } & Fill-in & Drained & \multicolumn{2}{c}{ Splits } \\
\cline { 5 - 5 } & & & Grcen peas & Yellow peas \\
\cline { 2 - 3 } & Ounces & Ounces & Percent & Percent \\
$180^{\circ}$ F. for 5 min. & 13 & 14.2 & 33.7 & 92.41 \\
$190^{\circ}$ F. for 7 min. & 13 & 13.5 & 24.6 & 88.88 \\
$195^{\circ}$ F. for 6 min. & 13 & 13.4 & 23.7 & 84.08 \\
$200^{\circ}$ F. for 5 min. & 13 & 13.8 & 36.98 & 89.58 \\
\hline
\end{tabular}

the color and turbidity of the brine of the canned peas. If the substances removed from the peas during the blanching treatment concentrate in the water unless the peas are thoroughly washed afterwards, it is to be expected that carryover of the blanch water may lead to a darkening of the brine and to an increase in the turbidity.

To determine the effect of the rate of flow of the make-up water through the blancher the following experiments were carried out. Pigeonpeas were processed continuously at an average rate of 500 pounds per hour. The processing line was operated for several hours. The rate of flow of water through the blancher was adjusted at 0.27 gallons per minute (g.p.m.) for one experiment and at 0.54 g.p.m. for the other. A third run was made in which the blancher was filled with water to the overflow level, but no make-up water was used throughout the run. Every half-hour a sample of the water from the blancher was taken and the turbidity measured. At the same time several cans coming out from the line were marked for analyses.

The effect of the rate of flow of the make-up water to the blancher on the turbidity of the water in the blancher is shown in figure 1. As can be 
seen, the turbidity of the water in the blancher increased rapidly when no water was admitted. At a flow of 0.27 g.p.m. less fouling of the water took place, but the curve shows that concentration of colored substances in the water in the blancher continued. When the rate of feed was 0.54 g.p.m. it

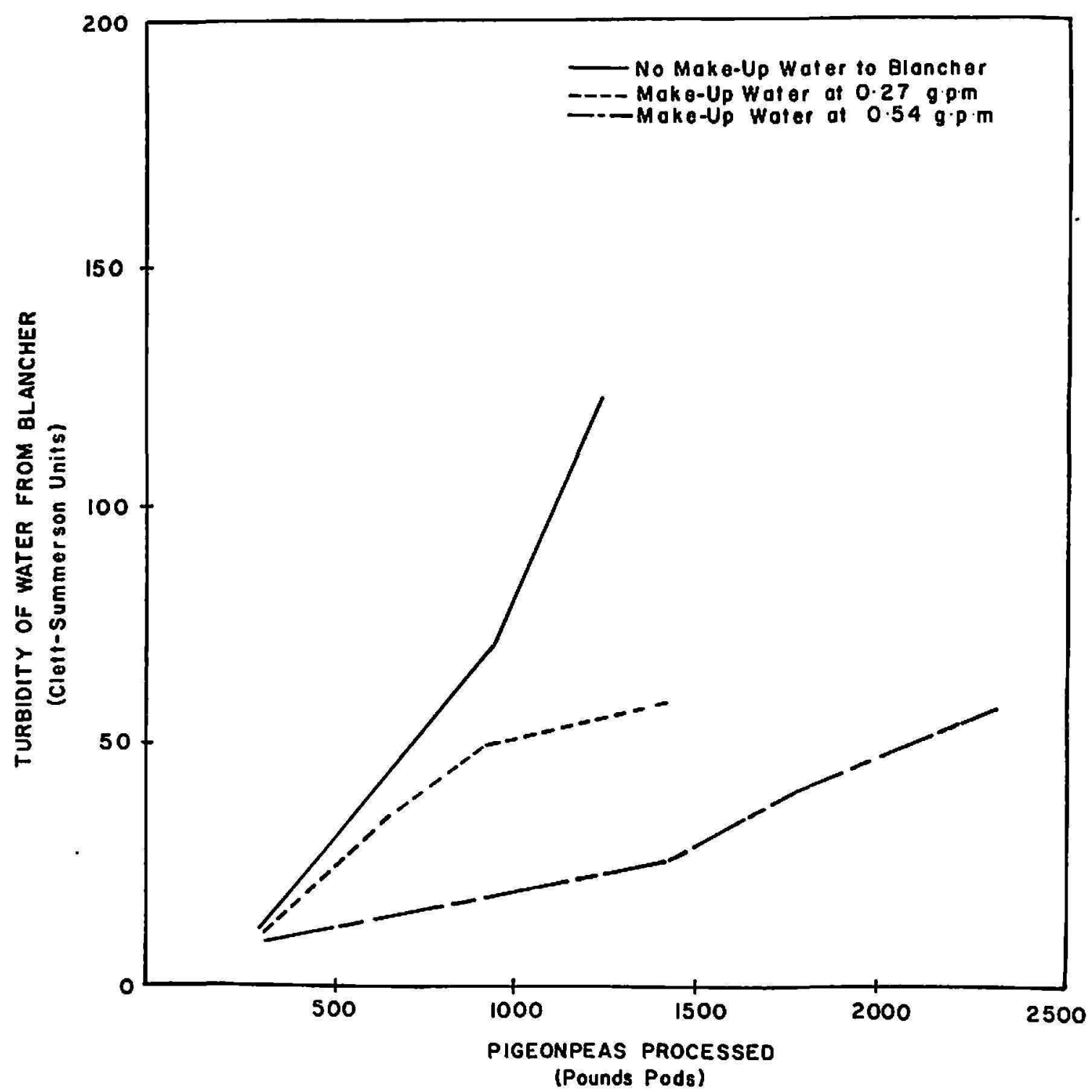

Fia. 1.-Effect of rate of flow of make-up water to the blancher on the turbidity of the water in the blancher.

was possible to reduce the fouling and the concentration of the colored substances, although the color and turbidity of the water was still increasing at the end of the experiment.

The canned samples taken from the line at regular intervals from each of the three experiments were opened 15 days later and the color and turbidity of the brine measured. The data obtained from these analyses are given in tables 6,7 , and 8 . When the color and turbidity of the brine were 
plotted against the pigeonpeas which had been processed by the time the samples were taken, the curves shown on figures 2 and 3 were obtained.

Examination of the data from these experiments shows that the first samples taken from the line had a low color and turbidity (figs. 2 and 3 ),

TABLE 6.-Turbidity of the brine of canned pigeonpeas blanched without admitting make-up water to blancher

\begin{tabular}{c|c|c|c|c}
\hline \multirow{2}{*}{ Sample No. } & \multicolumn{2}{|c|}{ Values for turbidity of brinc after processing the weight of pigeonpeas indicated } \\
\cline { 2 - 4 } & $300 \mathrm{lb}$. & $600 \mathrm{lb}$. & $900 \mathrm{lb}$. & $1,200 \mathrm{lb}$. \\
\hline 1 & 181 & 202 & 193 & 202 \\
2 & 196 & 193 & 220 & 206 \\
3 & 176 & 179 & 231 & 211 \\
\hline
\end{tabular}

TABLE 7.-Color and turbidily of brine of canned pigeonpeas when blanched with a rate of flow of make-up water to blancher of 0.27 g.p.m.

\begin{tabular}{c|c|c|c}
\hline $\begin{array}{c}\text { Pigeonpeas processed } \\
\text { (pounds) }\end{array}$ & $\begin{array}{c}\text { Turbidity of } \\
\text { blancher water }\end{array}$ & $\begin{array}{c}\text { Turbidity of the brine } \\
\text { of canned product }\end{array}$ & $\begin{array}{c}\text { Color of brine of } \\
\text { canned product }\end{array}$ \\
\cline { 2 - 3 } & 2 & 186 & 18.7 \\
30 & 14 & 222 & 15.8 \\
611 & 34 & 206 & 15.1 \\
916 & 45 & 212 & 17.9 \\
1,460 & 59 & 223 & 16.3 \\
\hline
\end{tabular}

TABLE 8.-Color and lurbidity of brine of canned pigeonpeas when blanched with a rate of flow of make-up water to blancher of $0.54 \mathrm{~g} . / \mathrm{m}$.

\begin{tabular}{c|c|c|c}
\hline $\begin{array}{c}\text { Unshelled pigeonpeas } \\
\text { processed (pounds) }\end{array}$ & $\begin{array}{c}\text { Turbidity of blancher } \\
\text { water }\end{array}$ & $\begin{array}{c}\text { Turbidity of brine of } \\
\text { canned product }\end{array}$ & $\begin{array}{c}\text { Color of brine of canned } \\
\text { product }\end{array}$ \\
\cline { 1 - 3 } & 12.2 & 194.0 & - \\
660 & 16.0 & 219.0 & 18.4 \\
1,000 & 20.5 & 187.5 & 16.9 \\
1,340 & 27.0 & 20.10 & 18.5 \\
1,680 & 47.1 & 216.0 & 18.9 \\
2,271 & 55.5 & 211.0 & 17.65 \\
\hline
\end{tabular}

but in samples taken later on the color and turbidity tend to level off. It is interesting to note that the samples taken from all three experiments had similar values for color and turbidity of the brine and showed about the same degree of variation among samples. In all three experiments, after the first 500 pounds of pods were processed, or the line was run for 1 hour, the values for color and turbidity of the brine of the canned product showed a 
tendency to level off, indicating that the rate of flow of the make-up water to the blancher had no effect on the color and turbidity of the brine.

Before reaching the conclusion that the rate of flow of make-up water to the blancher has no effect on the color and turbidity of canned pigeonpeas,

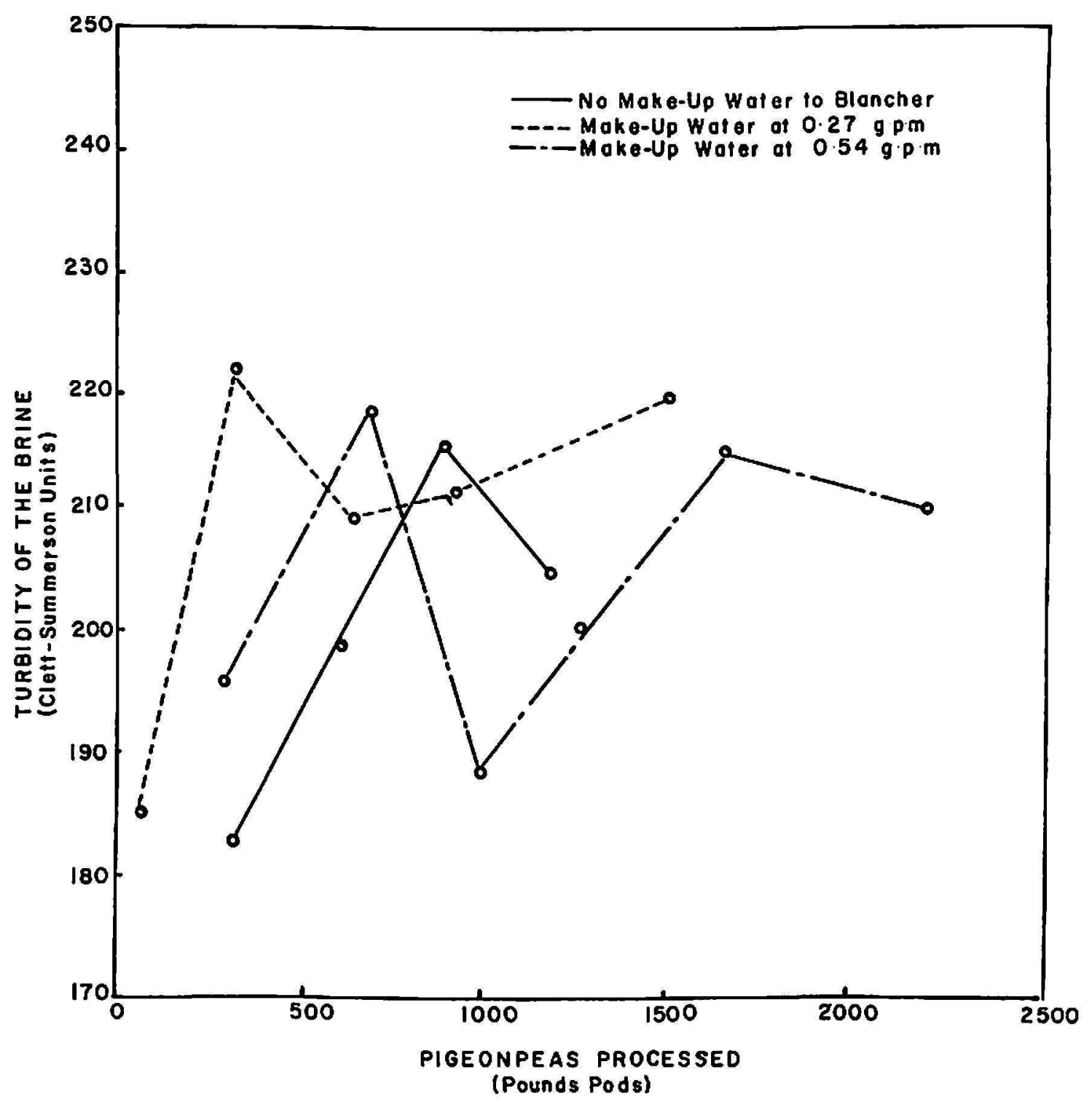

Fig. 2.-Effect of rate of flow of make-up water to the blancher on the turbidity of the brine of canned pigeonpeas.

it is necessary to consider the experimental conditions under which the experiments were run to see if the results obtained were caused by other processing variables.

The data in tables 6,7 , and 8 , and in figures 1,2 , and 3 show that the fouling of the water in the blancher had a direct relation to the rate of flow of the make-up water, but that the rate of flow of the water through the blancher had no effect on the color and turbidity of the brine of the canned 
pigeonpeas. If the fouling of the water in the blancher is directly related to the rate of flow, it is reasonable to expect that the turbidity and color of the brine of the canned product will be higher as the concentration of the color-substances increases, unless the washing treatment to which the peas

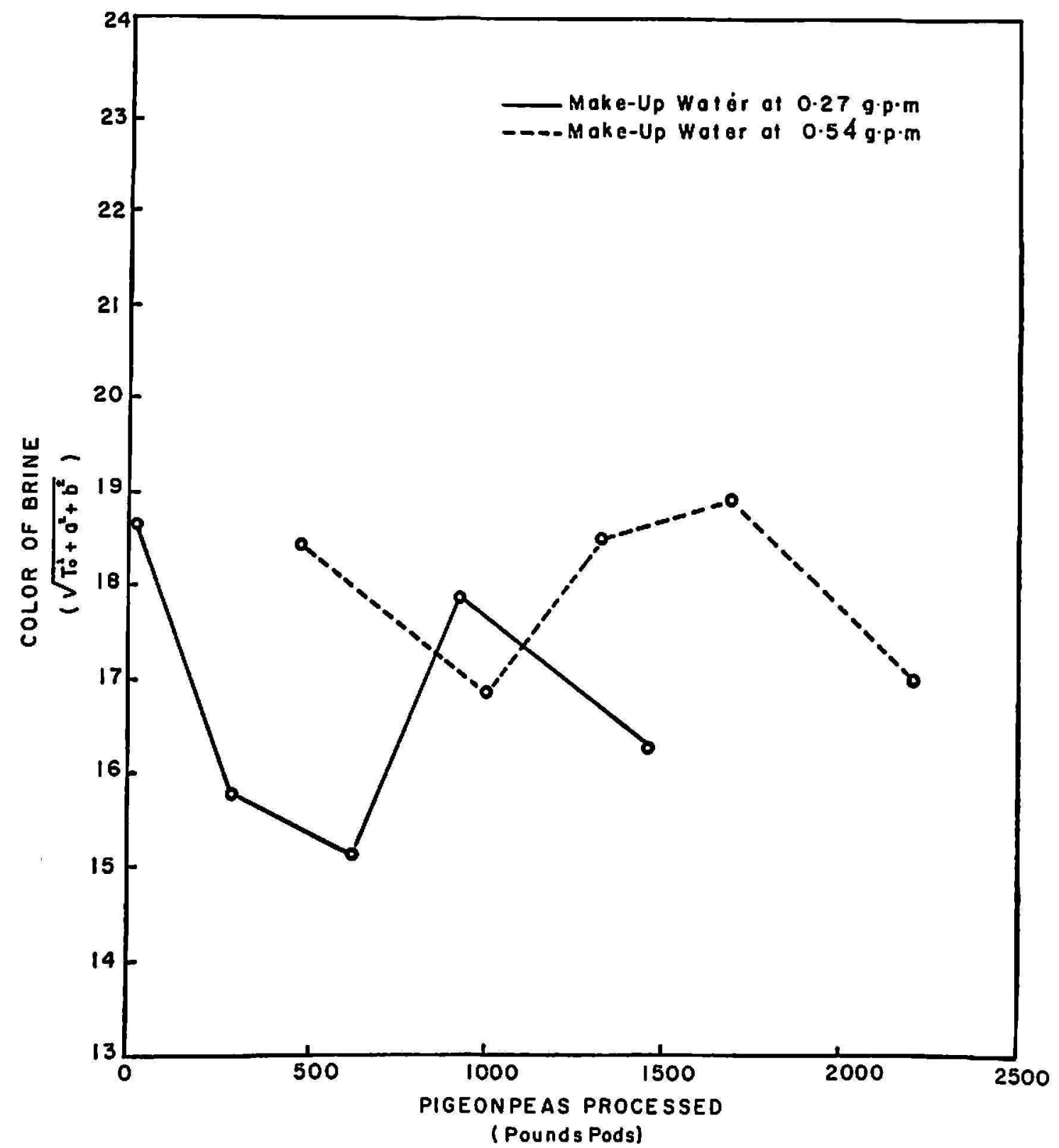

Fia. 3.-Effect of rate of flow of make-up water to the blancher on the color of the brine of canned pigeonpeas.

were subjected after blanching removed all the blanch water carried over with the peas.

In our processing line the blanched peas discharged into a rotary rod-reel washer where they were washed by water sprays. The washer is oversize in relation to the quantities of peas going through the line. Therefore, it prob- 
ably happened that washing of the peas at this stage removed all of the blancher water and thus fouling of the water had no effect in increasing the color and turbidity of the brine of the canned product.

The reader should be warned not to reach the conclusion that the rate of flow of the make-up water to the blancher will have no effect on the color and turbidity of the brine in commercial operations. This would be true only if the peas are thoroughly washed after blanching to make sure that all water carried over from the blanchers has been removed. The authors have frequently observed that some canners operate their blanchers with insufficient make-up water and, in many cases, it was noted that the overflow from the blancher was highly viscous and very dark. Unless the peas blanched under these undesirable conditions are thoroughly washed, it is reasonable to expect that carryover of the fouled water from the blancher will result in dark and turbid brines. Washing of the blanched peas should be considered essential in the production of a high-quality pack. Some processors have expressed the opinion that washing of the blanched peas should be eliminated since packing of the hot peas directly from the blancher will assure that the recommended initial temperature of $160^{\circ} \mathrm{F}$. is obtained. Enough evidence has been obtained from these experiments to show that washing of the blanched peas is essential in the processing and canning of high-quality products.

\section{EFFECT OF METALLIC CONTAMINATION ON THE COLOR}

AND TURBIDITY OF THE BRINE

In the first experiments we conducted all cans were filled by hand. Later on a filler with a stainless-steel hopper, but with a brass disk valve became available. It was observed that after the filler had been in use more turbid and highly colored brines were obtained than when all cans were hand-filled. To determine whether the filler was responsible for the increase in color and turbidity pigeonpeas from the same lot being processed were packed by both methods. Examination of the brine 15 days after canning showed that all samples packed using the filler had a deep color and higher turbidity than hand-packed samples. The data obtained from one of these experiments are given in the tabulation which follows, in which average values for all the samples examined are presented. It shows the effect of the use of a filler with a brass valve on the color and turbidity of the brine.

\begin{tabular}{lcc}
\multirow{2}{*}{ Characteristic } & \multicolumn{2}{c}{ Values for color and turbidity of the brine for samples packed } \\
as indicaled
\end{tabular}

The increase in the color and turbidity of the brine was found to be caused 
by the crushing of some of the peas between the two disks of the valve. The juice oozing out developed a dark discoloration when coming in contact with the brass. Drippage of this darkened juice into the cans being filled resulted in an increase in the color and turbidity of the brine.

It was also observed that whenever peas came in contact with galvanized iron, copper, or plain iron surfaces, not only the color and turbidity of the brine were adversely affected, but a bluish discoloration occurred in many of the peas. To avoid these undesirable changes it is essential when processing pigeonpeas that all of the metallic surfaces coming in contact with the product be of stainless steel.

TABLE 9.-Effect of holding-time before retorting on the color and turbidity of the brine and on the color of the canned pigeonpeas

\begin{tabular}{|c|c|c|c|}
\hline Cans processed (number) & Color of brine & Turbidity of brine & Color of peas \\
\hline 5 & 28.0 & 261 & 20.5 \\
\hline 20 & 30.5 & 242 & 19.7 \\
\hline 40 & 22.0 & 330 & 21.7 \\
\hline 60 & 28.2 & 230 & 21.8 \\
\hline 80 & 15.7 & 404 & 20.8 \\
\hline 100 & 27.9 & 256 & 20.0 \\
\hline 120 & 27.6 & 250 & 21.2 \\
\hline 140 & 23.8 & 270 & 20.2 \\
\hline 160 & 23.4 & 284 & 20.6 \\
\hline 180 & 26.4 & 276 & 21.4 \\
\hline
\end{tabular}

EFFECT OF HOLDING-TIME BEFORE RETORTING ON COLOR AND TURBIDITY OF BRINE AND ON COLOR OF CANNED PIGEONPEAS

In the commercial processing of pigeonpeas fillers and closing machines with a speed of 40 to 60 cans per minute are generally used. The cans are retorted in retorts which contain around 1,056 No. 2 cans. Disregarding any delays in the process, there is usually an interval of 18 to 30 minutes from the time the first and the last can for a retort load are closed. This means that every can stands near the filling temperature for a different length of time before retorting. In our pilot plant the capacity of our retorts was such that it also took us 30 minutes to produce enough cans for a retort load. To determine whether this variation in holding-time before retorting could be the cause of the wide range of values for color and turbidity that we had observed among samples from the same lot of pigeonpeas processed, cans were marked at regular intervals in the same sequence as canned. Fifteen days later the cans were opened and the color and turbidity of the brine and the color of the drained peas was measured. The data from one of these experiments are given in table 9. When values for the color and tur- 
bidity of the brine and for the color of the drained pigeonpeas were plotted against the number of cans processed the curves shown on figures 4,5 , and 6 were obtained. Examination of the data in the table and the curves shows

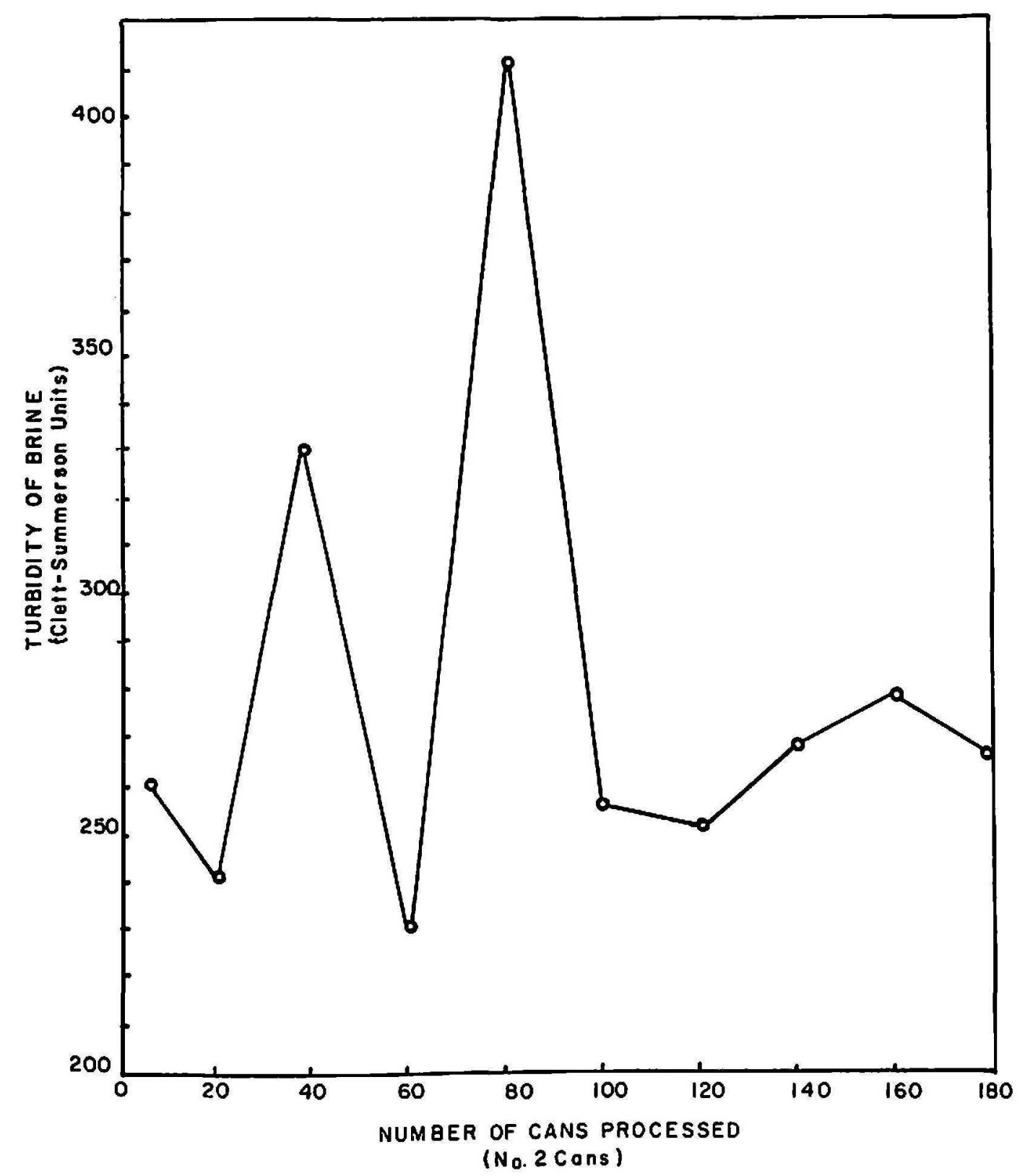

Fig. 4.-Effect of holding-time before retorting on the turbidity of the brine of canned pigeonpeas.

that the variation in the color and turbidity of the brine is not related to the holding-time before retorting. No change in the color of the drained peas could be observed among samples. The variation among samples is probably random and caused by some other processing variable. 


\section{EFFECT OF METHOD OF COOLING ON QUALITY OF THE CANNED PRODUCT}

Two methods of cooling the cans after retorting are generally used in the processing of pigeonpeas. The retort crates are transferred to a cooling tank

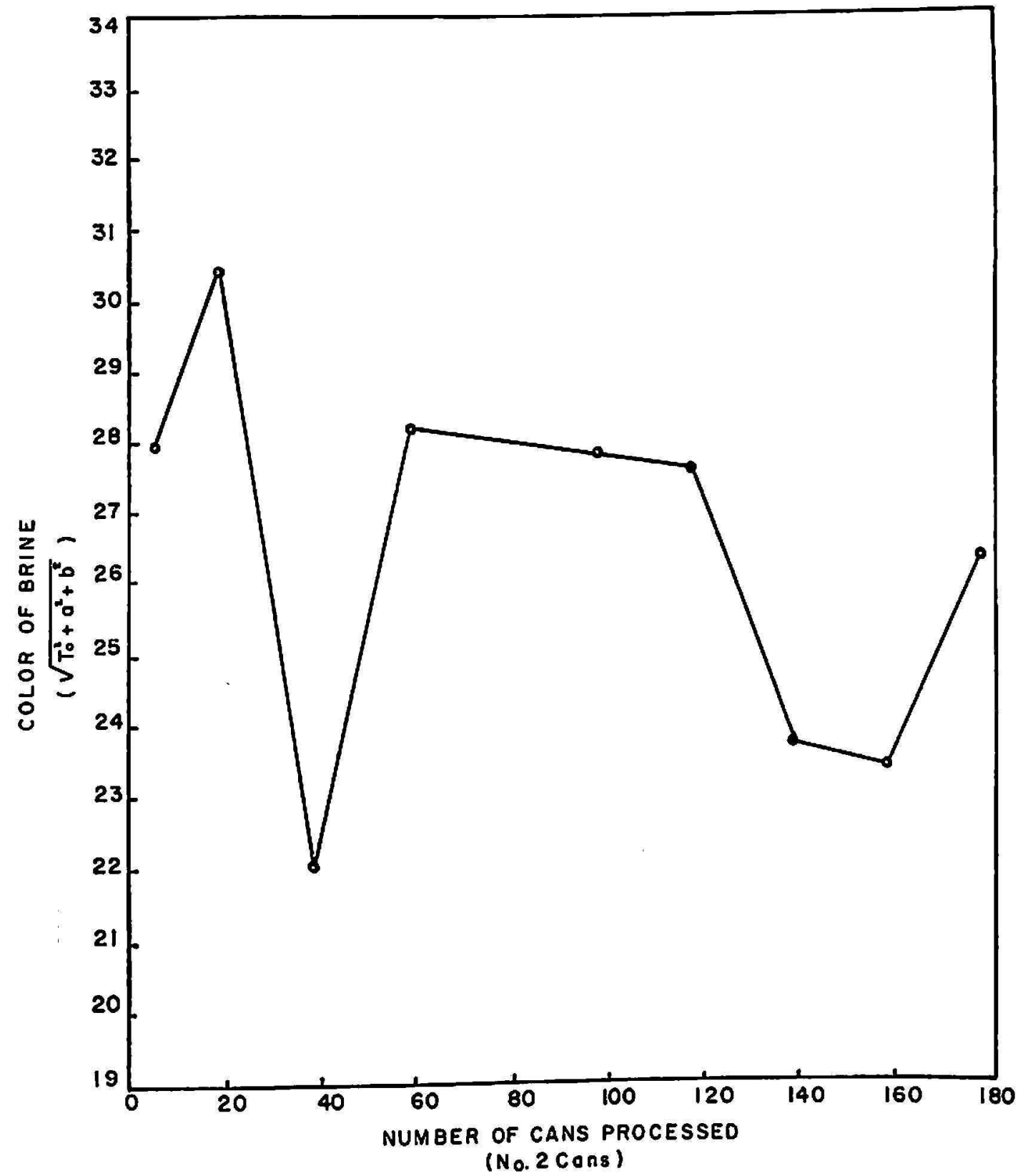

Fig. 5.-Effect of holding-time before retorting on the color of the brine of canned pigeonpeas.

or the cans are cooled in the open retort immediately after processing. The rate of cooling is different for both methods. When the cans are cooled in a tank, it usually takes about $\mathbf{4 0}$ minutes for the product temperature in the can to drop to $100^{\circ} \mathrm{F}$. When the cans are cooled in the retort by admitting water at a fairly fast rate, cooling may take place in no more than 15 minutes. 
To investigate the effect of the type and rate of cooling on the quality of the canned product several experiments were run in which the cans were cooled in a tank or in the retort immediately after processing. The data obtained from examination of the cans after holding for 15 days at room

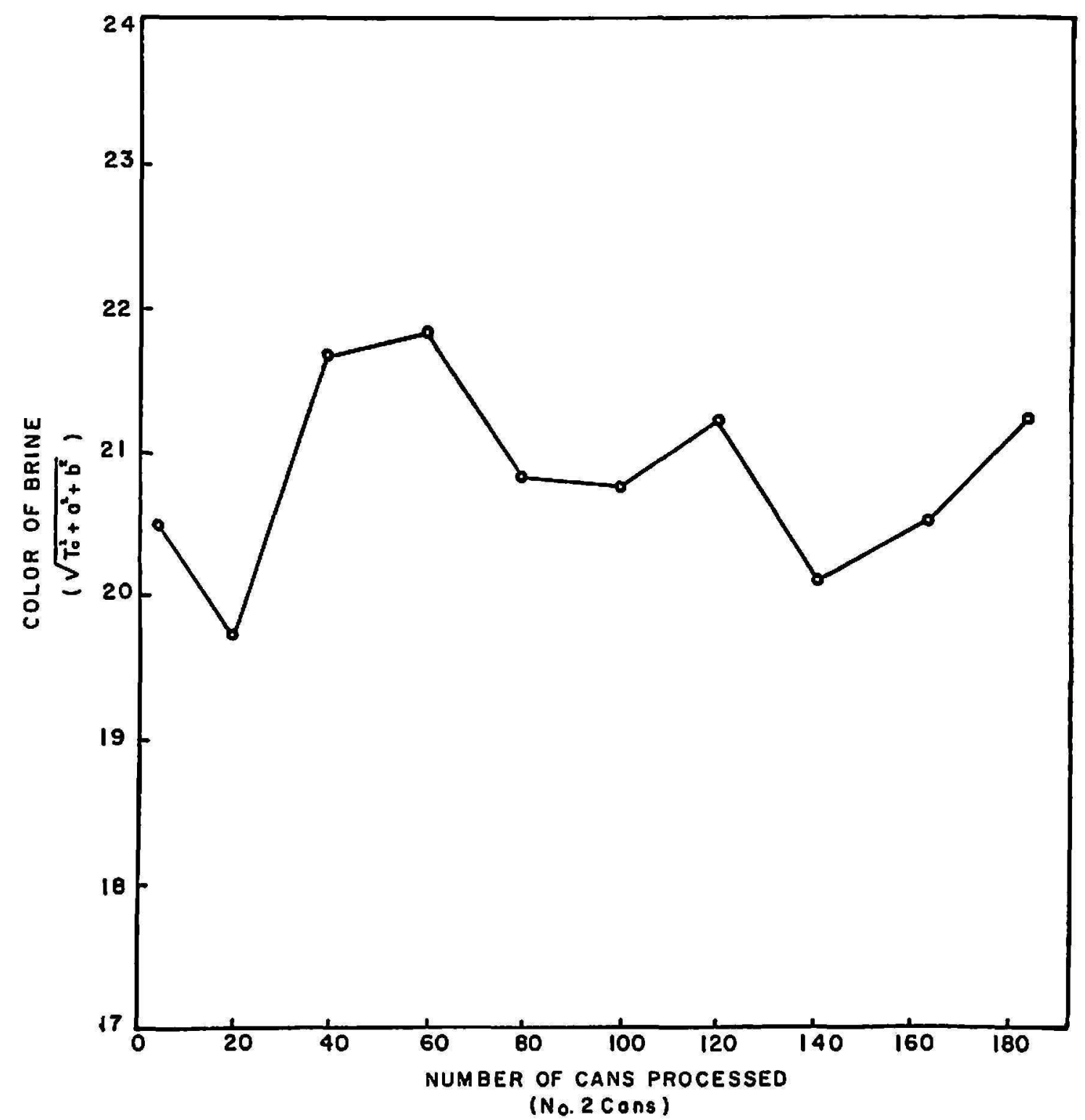

Fra. 6. -Effect of holding-time before retorting on the color of canned pigeonpeas.

temperature after processing are given in table 10 which shows the effect of a rapid cooling for 10 minutes and of a slow cooling for $\mathbf{4 5}$ minutes on the turbidity of the brine, on the percentage of peas with broken skins, and on the percentage of spotted peas. Statistical analysis of the data shows that the method of cooling has no effect on the turbidity of the brine, or the percentage of cracked or spotted peas. No significant difference was found when the color of the brine from 15 cans cooled in 45 minutes was compared with the color of the brine from 15 cans cooled in 10 minutes. 
The average color of the brine from cans cooled slowly was 30.82 and for the cans cooled in 10 minutes 29.45 .

EFFECT OF TYPE OF CAN ON QUALITY OF CANNED PIGEONPEAS

To test the effect of the type of can on the quality of the canned pigeonpeas, the lot being processed was divided into two equal parts. One part was canned in cans with plain tin bodies $(1.25 / \mathrm{BB})$ and C-enameled ends, the other part was canned in fully enameled (C-enamel) cans. Both types of cans received the same treatment after filling and were stored side by

TABLE 10.-Effect of slow and rapid cooling on the turbidity of brine and on number of defective pigeonpeas

\begin{tabular}{|c|c|c|c|c|c|c|}
\hline \multirow{2}{*}{ Experiment No. } & \multicolumn{2}{|c|}{ Turbidity } & \multicolumn{2}{|c|}{ Splits } & \multicolumn{2}{|c|}{ Percentage spotted peas } \\
\hline & Range & Mean & Range & Mean & Range & Mean \\
\hline \multicolumn{7}{|c|}{ Slow cooling -45 minutes } \\
\hline $\begin{array}{l}1 \\
2 \\
3\end{array}$ & $\begin{array}{l}217-450 \\
235-276 \\
266-305\end{array}$ & $\begin{array}{l}265 \\
258 \\
287\end{array}$ & $\begin{array}{l}73-83 \\
73-89 \\
62-72\end{array}$ & $\begin{array}{l}75.0 \\
82.0 \\
68.0\end{array}$ & $\begin{array}{l}8-20 \\
7-13 \\
4-14\end{array}$ & $\begin{array}{r}13.4 \\
9.6 \\
10.0\end{array}$ \\
\hline Mean & & 270.0 & & 75.0 & & 11.0 \\
\hline \multicolumn{7}{|c|}{ Rapid cooling $-8-10$ minutes } \\
\hline $\begin{array}{l}1 \\
2 \\
3\end{array}$ & $\begin{array}{l}251-290 \\
255-290 \\
199-294\end{array}$ & $\begin{array}{l}263 \\
276 \\
253\end{array}$ & $\begin{array}{l}76-90 \\
55-70 \\
69-86\end{array}$ & $\begin{array}{l}84.0 \\
65.0 \\
76.0\end{array}$ & $\begin{array}{l}4-14 \\
4-9 \\
9-17\end{array}$ & $\begin{array}{r}8.6 \\
6.4 \\
13.6\end{array}$ \\
\hline Mean & & 264 & & $\mathbf{7 5 . 0}$ & & 9.53 \\
\hline
\end{tabular}

side at room temperature before inspection and analysis. The quality of the product was determined in three ways: Evaluation for grade following the standards for canned pigeonpeas of the Commonwelath of Puerto Rico Department of Agriculture; measurement of the color and turbidity of the brine; organoleptic appraisal by a panel of trained tasters selected from the Laboratory staff. Since analyses and inspection of the cans a few days after processing may not indicate differences in quality due to the type of cans used, the samples were analyzed at frequent intervals throughout a year. The results obtained from these experiments are shown in tables 11, 12 , and 13.

Table 11 shows the effect of the type of can on the quality and keeping quality of canned pigeonpeas as determined from the evaluation of grade after the storage period indicated and following the standards of the Com- 
monwealth Department of Agriculture. The data show that the type of can used had no appreciable effect on the grade of the canned product, even after the cans had been in storage at room temperature for nearly 1 year.

TABLE 11.-Effect of type of can on the quality and keeping quality of canned pigeonpeas stored at $85^{\circ} \mathrm{F}$.

\begin{tabular}{|c|c|c|c|c|c|c|c|c|c|c|}
\hline \multirow{3}{*}{ Quality criteria } & \multicolumn{10}{|c|}{ Values after storage period indicated in - } \\
\hline & \multicolumn{5}{|c|}{ Plain tin cans with C-enamel } & \multicolumn{5}{|c|}{ Fully enameled cans } \\
\hline & $\begin{array}{c}55 \\
\text { days }\end{array}$ & $\begin{array}{r}149 \\
\text { days }\end{array}$ & $\begin{array}{r}226 \\
\text { days }\end{array}$ & $\begin{array}{l}300 \\
\text { days }\end{array}$ & $\begin{array}{r}363 \\
\text { days }\end{array}$ & $\begin{array}{c}55 \\
\text { days }\end{array}$ & $\begin{array}{c}149 \\
\text { days }\end{array}$ & $\begin{array}{r}226 \\
\text { days }\end{array}$ & days & $\begin{array}{c}363 \\
\text { days }\end{array}$ \\
\hline Liquor classification & 14 & 12 & 13 & 13 & 11 & 14 & 11 & 13 & 13 & 12 \\
\hline Color of peas & $|23.9|$ & 25 & 24 & 24 & 23 & 24 & 23 & 21 & 24 & 20 \\
\hline Defects & 29.5 & 26 & 27 & 29 & 25 & 29.5 & 24 & 27 & 29 & 29 \\
\hline Character & 29.9 & 26 & 24 & 27 & 26 & 29.9 & 24 & 27 & 27 & 28 \\
\hline Rating & 97.3 & 90 & 88 & 93 & 85 & 96 & 87 & 88 & 93 & 89 \\
\hline
\end{tabular}

TABLE 12.-Effect of type of can on the color and turbidity of the brine of canned pigeonpeas

\begin{tabular}{|c|c|c|c|c|c|c|c|c|c|c|c|c|}
\hline \multirow{3}{*}{$\begin{array}{l}\text { Characteristic } \\
\text { of brine }\end{array}$} & \multicolumn{12}{|c|}{ Values after storage period indicated in- } \\
\hline & \multicolumn{3}{|c|}{$\begin{array}{l}\text { Plain tin cans with } \\
\text { C-enameled ends }\end{array}$} & \multicolumn{3}{|c|}{ Fully enameled cans } & \multicolumn{3}{|c|}{$\begin{array}{c}\text { Plain tin cans with } \\
\text { C-enameled ends }\end{array}$} & \multicolumn{3}{|c|}{ Fully enameled cans } \\
\hline & $\begin{array}{c}55 \\
\text { days }\end{array}$ & \begin{tabular}{|c|}
226 \\
days
\end{tabular} & $\begin{array}{r}363 \\
\text { days }\end{array}$ & $\begin{array}{c}55 \\
\text { days }\end{array}$ & \begin{tabular}{|}
226 \\
days
\end{tabular} \mid & $\begin{array}{c}363 \\
\text { days }\end{array}$ & $\begin{array}{c}55 \\
\text { days }\end{array}$ & $\begin{array}{r}226 \\
\text { days }\end{array}$ & $\begin{array}{c}363 \\
\text { days }\end{array}$ & $\begin{array}{c}55 \\
\text { days }\end{array}$ & $\begin{array}{c}226 \\
\text { days }\end{array}$ & $\begin{array}{c}363 \\
\text { days }\end{array}$ \\
\hline $\begin{array}{l}\text { Color } \\
\text { Turbidity }\end{array}$ & $\begin{array}{r}32.9 \\
308.0\end{array}$ & $\begin{array}{r}24.8 \\
221.0\end{array}$ & $\begin{array}{r}36.8 \\
224.0\end{array}$ & $\begin{array}{r}49.8 \\
268.0\end{array}$ & $\begin{array}{r}37.2 \\
165.0\end{array}$ & $\begin{array}{r}41.0 \\
174.0\end{array}$ & $\begin{array}{r}36.8 \\
312.0\end{array}$ & $\begin{array}{r}24.8 \\
188.0\end{array}$ & $\begin{array}{r}38.8 \\
256.0\end{array}$ & $\begin{array}{r}47.8 \\
283.0\end{array}$ & $\begin{array}{r}33.0 \\
179.0\end{array}$ & $\begin{array}{r}52.2 \\
160.5\end{array}$ \\
\hline
\end{tabular}

TABLE 13.-Effect of type of can on the quality of \& lots of canned pigeonpeas as judged by tasters

\begin{tabular}{l|c|c|c|c}
\hline \multirow{2}{*}{ Characteristic } & \multicolumn{2}{|c|}{ Lot A } & \multicolumn{2}{c}{ Lot B } \\
\cline { 2 - 6 } \cline { 4 - 5 } & Plain tin cans & $\begin{array}{c}\text { C-enameled } \\
\text { cans }\end{array}$ & Plain tin cans & $\begin{array}{c}\text { C-enameled } \\
\text { cans }\end{array}$ \\
\hline $\begin{array}{c}\text { Appearance of product in the } \\
\text { can }\end{array}$ & 2.64 & 3.73 & 3.00 & 4.00 \\
Appearance of brine in the can & 3.09 & 4.64 & 3.27 & 4.82 \\
\hline
\end{tabular}

Color and turbidity measurements from both types of cans throughout the storage period are given in table 12 . The color and turbidity of the brine from the fully enameled cans was somewhat lower than from the plain tin cans with C-enameled ends. 
The results of the organoleptic comparisons of the products from both types of cans are shown in table 13. Tasters generally found the appearance of the product in the can better for the enameled can, and the appearance of the brine in the can much better. No difference in flavor or intensity of off-flavors could be found between the samples in the plain tin or enameled cans. It was observed that the number of peas with a bluish discoloration were greater in the plain tin cans.

The results of these tests show that brines of lighter color and lower turbidity can be obtained when pigeonpeas are canned in enameled cans. Tasters were able to establish a difference in the color and turbidity of the brine when the pigeonpeas were presented to them in the open can. The difference in the color and turbidity of the samples, or the fact that less discolored peas could be found in the enameled cans, made no difference in the grading of the product according to the existing standards. Since it is possible to obtain A-grade products when using plain tin cans with C-enameled ends, the use of the more expensive fully enameled can is not justified.

\section{OTHER FACTORS AFFECTING THE QUALITY OF CANNED PIGEONPEAS}

In the course of our work all canned samples were generally analyzed and graded after storage for 15 days at room temperature. However, in many experiments it was necessary to measure the color and turbidity of the brine of the canned product immediately after canning, or a few days later. Since the keeping-quality studies with the product canned in plain tin cans and in fully enameled cans showed that, during storage at room temperature (see table 12) the color and turbidity of the brine improved, it was suspected that measuring the color and turbidity at any interval within the stabilization period of 15 days might cause a greater variation among samples than could be expected from random variation due to sampling. The data shown in table 14 were obtained when canned pigeonpeas were stored at a room temperature of $85^{\circ} \mathrm{F}$. and a can was opened every day until the 15 days for the measurement of the color and turbidity of the brine. When the color and turbidity of the brine were plotted against the storage period in days, as shown on figures 7 and 8 , no true relation could be found between the length of storage during the first 15 days and the color and turbidity of the brine.

The analysis and inspection of a large number of cans in which the headspace as well as the color and turbidity of the brine were measured suggested that darkening of the brine may be related to the head-space. The data collected from a large number of cans examined are given in table 15. Statistical analysis of the data showed that there was high correlation between head-space and the color or turbidity of the brine. The results of the statistical analyses of the data in table 15 are given in the following tabulation for correlation coefficients during 30 observations. 
Charaeteristic

Color of the brine

Turbidity of the brine
Experimental

0.622

$-.601$
Al 1-percent level of

signicance

0.463

.463

The direct effect of head-space on the color and turbidity of the brine explains the great variation that had been observed among samples for these two quality criteria even within the same lot. Since it is almost impossible to obtain cans with the same head-space, great variation in the color and turbidity of the brine are to be expected.

TABLE 14.-Changes in the color and turbidity of brine of canned pigeonpeas during the first 15 days of storage at $85^{\circ} F$. for $\&$ lots processed

\begin{tabular}{c|c|c|c|c}
\hline \multirow{2}{*}{$\begin{array}{c}\text { Storage period } \\
\text { (days) }\end{array}$} & \multicolumn{2}{|c|}{ Turbidity } & \multicolumn{2}{|c}{ Color } \\
\cline { 2 - 5 } \cline { 4 - 5 } & Lot A & Lot B & Lot A & Lot B \\
\hline 1 & 244 & 251 & 17.8 & 25.4 \\
2 & 243 & 231 & 37.2 & 32.0 \\
3 & 210 & 221 & 35.5 & 23.4 \\
4 & 269 & 278 & 30.0 & 22.5 \\
5 & 226 & 260 & 29.1 & 29.8 \\
6 & 213 & 232 & 30.0 & 24.3 \\
7 & 219 & 240 & 35.5 & 30.0 \\
8 & 212 & 253 & 26.0 & 26.2 \\
9 & 206 & 244 & 26.1 & 28.4 \\
10 & 340 & 256 & 17.8 & 30.5 \\
11 & 267 & 258 & 26.7 & 30.2 \\
12 & 257 & 278 & 19.7 & 23.6 \\
13 & 210 & 238 & 35.9 & 28.0 \\
14 & 228 & 310 & 24.8 & 29.3 \\
15 & 325 & - & 31.8 & 16.2 \\
\hline
\end{tabular}

It was also observed that head-space had an effect on the discoloration of the peas. In all cans examined and found to have a large head-space, the upper layer of pigeonpeas showed a pronounced bluish discoloration. Although precise control of head-space may not be possible in commercial processing, canners should try to fill the cans adequately to avoid excessive head-space. A small head-space will make it possible to obtain a canned product with a brine of low color and turbidity, and to reduce the number of discolored peas.

\section{USE OF CALCIUM CHLORIDE TO REDUCE CRACKS AND SPLITS}

As was already mentioned, pigeonpeas usually crack during processing. The tendency to crack is related to the maturity; the more mature the peas the higher the number of cracks and splits found in the canned product. 
When mature pigeonpeas are processed, the large number of cracks not only detracts from the appearance of the product, but more starch becomes dispersed in the brine and brines of high turbidities are obtained.

Calcium chloride is one of the most used firming agents to prevent soft-

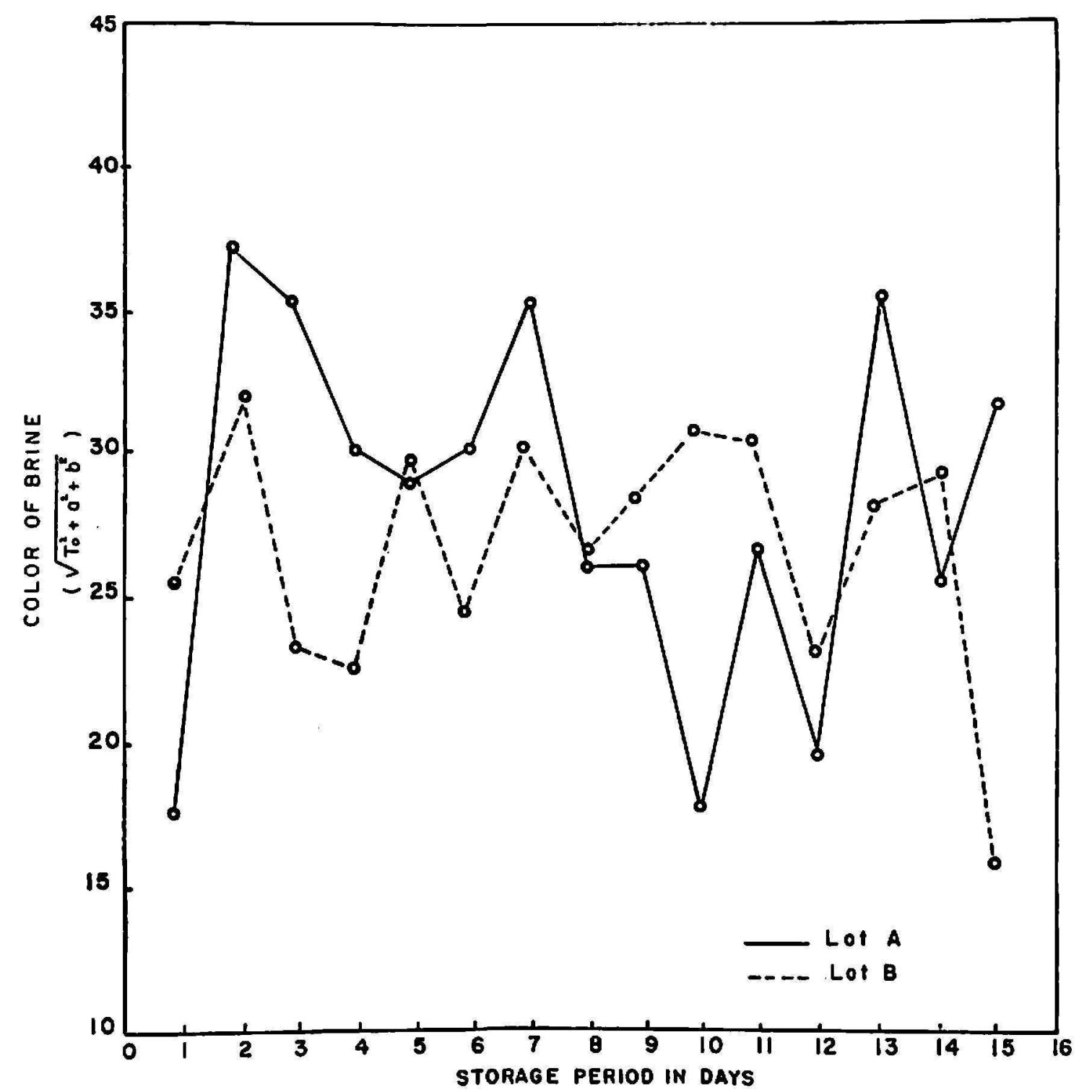

Frg. 7.-Changes in color of the brine of canned pigeonpeas during the first 15 days of storage at $85^{\circ} \mathrm{F}$.

ening of fruits during processing. It is believed that by reacting with the pectin, calcium chloride forms insoluble pectates which strengthen the cellular structure. The possibility of preventing or reducing the number of cracks by the use of a low concentration of calcium chloride during blanching as well as by the addition of calcium chloride to the brine was investigated. 


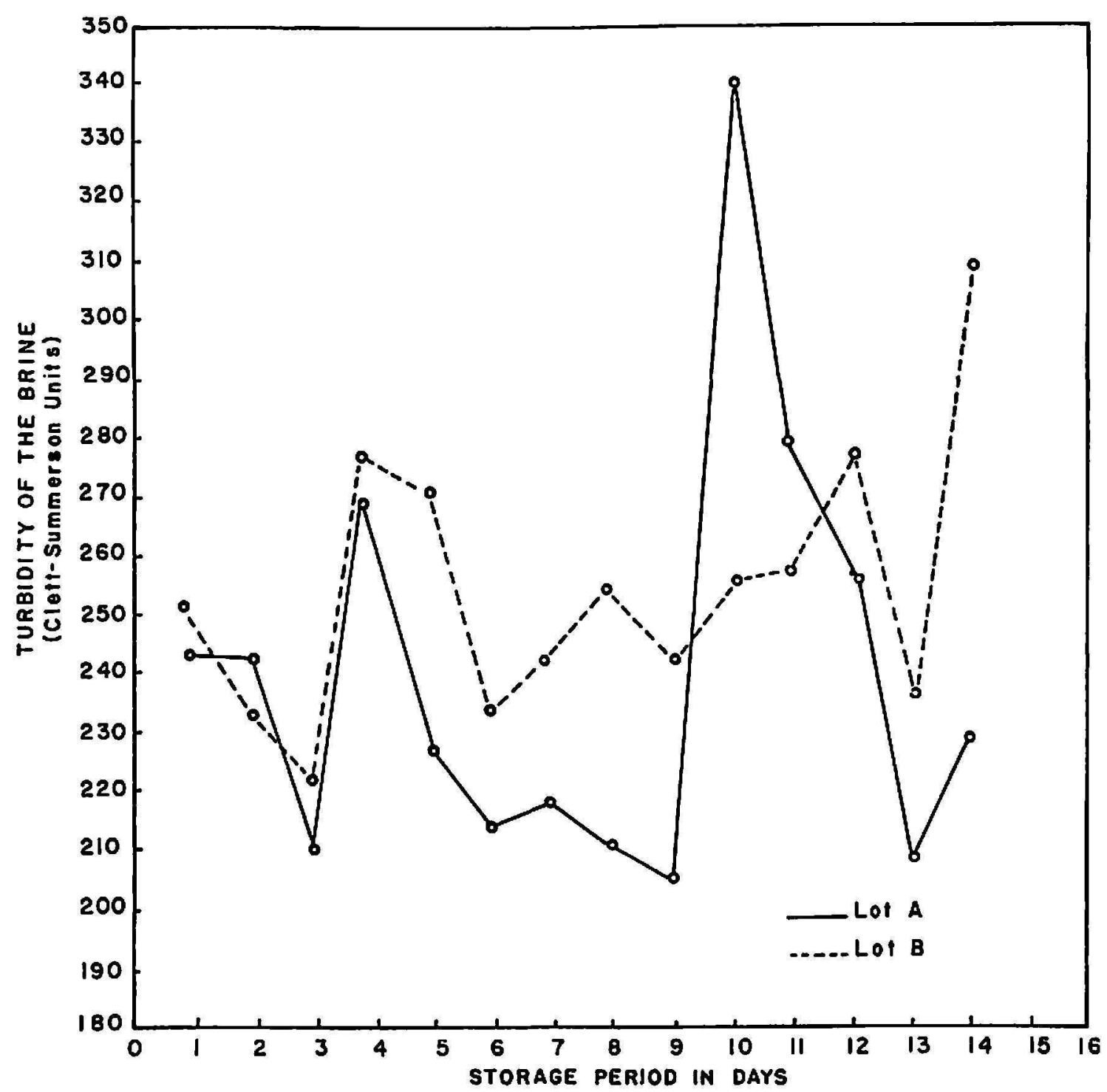

Fig. 8.-Changes in the turbidity of the brine of canned pigeonpeas during the first 15 days of storage at $85^{\circ} \mathrm{F}$.

TABLE 15.-Color and turbidity of brine from 30 cans of pigeonpeas examined with different head-space

\begin{tabular}{c|c|c|c|c}
\hline \multirow{2}{*}{$\begin{array}{c}\text { Head-space (six- } \\
\text { teenths of an inch) }\end{array}$} & \multicolumn{2}{|c|}{ Color of brine } & \multicolumn{2}{c}{ Turbidity of brine } \\
\cline { 2 - 5 } & Range & Average & Range & Average \\
\hline 0 & $46.01-56.91$ & 51.30 & $152.0-182.5$ & 165.3 \\
.5 & $32.69-51.09$ & 42.96 & $173.0-194.9$ & 187.7 \\
1 & $30.53-47.41$ & 42.96 & $155.0-225.8$ & 191.2 \\
1.5 & $32.13-48.76$ & 38.22 & $174.0-190.2$ & 184.4 \\
2.0 & $31.29-43.36$ & 37.51 & $189.0-229.5$ & 202.6 \\
3.0 & $27.08-40.93$ & 31.88 & $221.2-299.0$ & 263.9 \\
\hline
\end{tabular}


When pigeonpeas were blanched in water containing $0,0.1,0.2,0.3$, and 0.4 percent of calcium chloride by weight, the number of cracks were found to be reduced when the chemical was added to the blanch water. The hardness of the peas increased with the concentration of calcium chloride as can be seen from the data in table 16 . When the pigeonpeas which underwent

TABLE 16.-Effect of blanching in calcium chloride solution on the tenderness of pigeonpeas

\begin{tabular}{l|c|c|c}
\hline \multicolumn{1}{c|}{ Blanching treatment } & $\begin{array}{c}\text { Concentration of } \\
\text { CaCls by weight }\end{array}$ & Peas with cracks & Hardness \\
\cline { 1 - 2 } & Percent & Percent & Lb./sg. in. \\
\cline { 1 - 2 } $195^{\circ}$ F. for 4 min. & 0 & 62.21 & 1.67 \\
$195^{\circ}$ F. for 3 min. & .1 & 54.63 & 2.78 \\
$195^{\circ}$ F. for 3 min. & .2 & 38.68 & 2.89 \\
$195^{\circ}$ F. for 3 min. & .3 & 36.71 & 3.83 \\
$195^{\circ}$ F. for 3 min. & .4 & 34.47 & 4.17 \\
\hline
\end{tabular}

TABLE 17.-Effect of the addition of $\mathrm{CaCl}_{2}$ to the brine on the color and turbidity of the brine and on the rupturing of the epicarp and formation of split pigeonpeas

\begin{tabular}{|c|c|c|c|c|c|c|c|}
\hline \multirow{2}{*}{ Factor determined } & \multicolumn{7}{|c|}{ Values for difierent quantities of $\mathrm{CaCl}_{2}$ added as indicated } \\
\hline & $\mathbf{0}$ & 5 grains & 6 grains & 9 grains & 11 grains & 14 grains & 18 grains \\
\hline Drained weight.... ounces & 14.0 & 12.0 & 12.0 & 12.0 & 12.0 & 12.0 & 12.0 \\
\hline Turbidity of brine & 323.0 & 302.0 & 274.0 & 274.0 & 272.0 & 300.0 & 309.0 \\
\hline $\begin{array}{l}\text { Color of brine } \\
\text { Viscosity of brine flow }\end{array}$ & 25.7 & 31.8 & 36.6 & 36.6 & 50.2 & 37.9 & 35.2 \\
\hline seconds at $28^{\circ} \mathrm{C}$. & 16.0 & 6.1 & 6.1 & 6.1 & 5.8 & 5.4 & 5.6 \\
\hline $\begin{array}{l}\text { Volume of brine.......ml. } \\
\text { Peas with broken epicarp }\end{array}$ & 184.0 & 244.0 & 254.0 & 232.0 & 一 & 244.0 & 250.0 \\
\hline$\ldots \ldots \ldots \ldots \ldots$ percent & 82.5 & 9.8 & 8.3 & 6.4 & 19.8 & 12.3 & 13.3 \\
\hline $\begin{array}{l}\text { Splits............. do. } \\
\text { Alcohol-insoluble solids. }\end{array}$ & 9.2 & 2.5 & 3.52 & 3.85 & 6.9 & 4.2 & 1.2 \\
\hline Overripe yellow peas in & 22.2 & 25.1 & 25.7 & 25.5 & 25.9 & 25.7 & 26.0 \\
\hline the can........number & 126.0 & 48.0 & 60.0 & 84.0 & 132.0 & 48.0 & 108.0 \\
\hline
\end{tabular}

the calcium chloride treatment were submitted to organoleptic evaluation, tasters found them too hard and unacceptable, even at the lower concention of 0.1 percent.

When calcium chloride was added to the can in the form of a salt-calcium chloride tablet, similar results were obtained, as can be seen from the data in table 17. The use of calcium chloride reduced the absorption of water, and lower drained weights were obtained in the treated samples. 
The turbidity, color, and viscosity of the brine were improved by the addition of the chemical. Both the percentage of pigeonpeas with cracks, as well as the number of maturity cracks in the can, were notably reduced.

When the samples treated with calcium chloride at the level shown in table 17 were compared organoleptically among themselves, as well as with a control containing no calcium chloride, tasters found the appearance of the product in the can much better in the treated samples than in the control, the difference being highly significant.

No difference could be found among the treated samples. Tasters likewise found a significant difference in tenderness between control and the treated samples, but no difference in tenderness among the treated samples. All treated samples were found unacceptable by tasters because of excessive

TABLE 18.-Effect of the addition of 2 percent of sugar and 75 grains of salt to the brine on the quality of canned pigeonpeas

\begin{tabular}{l|r|r|r|r|r|r}
\hline \multirow{2}{*}{\multicolumn{1}{c|}{ Characteristic }} & \multicolumn{5}{|c}{ Values after storage period and additions indicated } \\
\cline { 2 - 6 } & \multicolumn{3}{|c|}{75 grains NaCl } & 75 grains $\mathrm{NaCl}+2$ percent of sugar \\
\cline { 2 - 6 } & 64 days & 147 days & 365 days & 64 days & 147 days & 365 days \\
\hline Liquor classification & 14.0 & 13.0 & 12.0 & 14.0 & 13.0 & 13.0 \\
Color rating & 24.6 & 24.0 & 21.0 & 24.5 & 24.0 & 22.0 \\
Defect rating & 29.8 & 28.0 & 28.0 & 29.6 & 28.0 & 29.0 \\
Character & 29.9 & 30.0 & 30.0 & 30.0 & 30.0 & 25.0 \\
Overall rating & 98.1 & 95.0 & 91.0 & 97.9 & 97.0 & 89.0 \\
Turbidity of brine & 278.0 & 298.0 & 257.0 & 283.0 & 282.0 & 198.9 \\
Color of brine & 31.2 & 41.6 & 32.1 & 41.5 & 47.5 & 42.8 \\
\hline
\end{tabular}

hardness. Cooking of the treated peas had no effect in reducing the objectionable hardness.

\section{ADDITION OF SUGAR TO THE BRINE}

Many processors feel that the canned pigeonpeas are greatly improved by the addition of sugar. Since the levels of sugar generally used never exceed 2 percent, the effect of adding 2 percent of sugar to the brine was investigated. Pigeonpeas from the same lot were canned with and without sugar and stored at $85^{\circ} \mathrm{F}$. for a year. At regular intervals the cans were graded and submitted to organoleptic appraisal. The results of the grading of the canned product three times throughout the year are given in table 18, which shows that the addition of sugar had no appreciable effect on the quality of the final product. No difference between the two samples could be discerned when pigeonpeas canned with and without sugar were sub- 
mitted to tasters in pairs for flavor comparisons. Therefore, the addition of 2 percent of sugar to the brine may be regarded as having no effect on the quality and flavor of canned pigeonpeas.

\section{RECOMMENDATIONS}

Assuming that pigeonpeas are at optimum maturity for processing, the storage of the pods, presteaming or heating the pods before shelling to inactivate the enzyme system, blanching, and filling are the critical steps that determine the quality of the pack.

Storage of the pods in jute bags at room temperature results in a rapid deterioration of the quality of the raw material. All efforts to harvest the peas at the optimum maturity for processing will be wasted if the pods are improperly handled and stored. Storage at $45^{\circ} \mathrm{F}$. allowing maximum air circulation for rapid cooling provides the best means of maintaining the freshness of the product for a storage period of at least 9 days.

Steaming the pods before shelling to inactivate the enzyme system has been shown (1) to be essential to producing canned pigeonpeas with almost colorless brines. Inactivation of the enzyme system before shelling is not the only factor determining the quality of the pack when judged from the color and turbidity of the brine.

The length of the blanching treatment has a direct effect on the color and turbidity of the brine. Although it is true that the longer the blanch period the lighter the color of the brine, an excessively long blanch should be avoided to reduce the leaching out of vitamins and minerals. A blanching treatment of 5 minutes at $185^{\circ} \mathrm{F}$. is adequate.

The rate of flow of the make-up water to the blancher should be sufficient to avoid excessive fouling. Even if some fouling takes place a high-quality pack can be obtained, provided the blanched peas are thoroughly washed and drained. Failure to wash and drain the peas at this stage will cause darkening and increased turbidity of the brine.

The color and turbidity of the brine, as well as discoloration of the peas, is also related to head-space. Excessive head-space will result in highly colored and turbid brines and in discolored peas.

The use of metals like iron, brass, or copper in equipment coming in contact with the pigeonpeas also leads to a darkening of the brine. Use of stainless-steel prevents the development of color by reducing the possibility of metallic contamination.

\section{SUMMARY}

The effect of a number of processing variables on the quality of canned pigeonpeas was studied. Storage of the unshelled peas at $4 i^{\circ} \mathrm{F}$. for 9 days had no appreciable effect on the quality of the canned product. The length of the blanching treatment was found to determine to a certain degree the 
color and turbidity of the brine. The longer the blanching treatment the clearer and less turbid are the brines. The rate of flow of make-up water to the blancher had no effect on the color and turbidity of the brine, provided the blanched peas were thoroughly washed and drained before canning.

Holding-time before retorting and length of cooling of the cans had no effect on the quality of the canned product. Contact of pigeonpeas with iron, brass, or copper surfaces was found to result in brine discoloration. Excessive head-space was found to result in highly colored and turbid brines and peas discolored bluish. The type of can used, whether plain tin with C-enameled ends, or the fully enameled, had no appreciable effect on the quality of the canned product.

When the pigeonpeas are blanched in calcium chloride solutions or calcium chloride is added to the can, the number of cracks in the canned peas can be reduced, but the peas become so tough as to render them inedible. The addition of 2 percent of sugar to the brine was found to have no effect on the flavor or the overall quality of canned pigeonpeas.

Based on the results of the experiments reported, recommendations are given about the best process to use in canning high-quality pigeonpeas.

\section{RESUMEN}

Se llevó a cabo un estudio sobre las distintas etapas que comprende el procedimiento de elaborar gandures para determinar cómo se afecta la calidad del producto después de enlatado. Primeramente, se estudió cómo se afectan las vainas sometidas a una temperatura de $45^{\circ} \mathrm{F}$., luego de comprobarse la posibilidad de almacenar el gandur a esta temperatura, por nueve días, sin que la calidad del producto enlatado se afecte adversamente.

Un estudio del método de escaldado demostró que la duración de este proceso es responsable del color y la turbiedad de la salmuera al enlatar el producto. Así, cuando el escaldado se prolonga, se obtienen salmueras de color más claro. El flujo del agua de reemplazo que va al escaldador no ejerce efecto alguno sobre la calidad del producto, siempre que el grano escaldado se lave y escoja cuidadosamente.

El tiempo que transcurre desde el momento en que las latas se llenan hasta que se esterilizan, no surte efecto nocivo sobre la calidad del producto, ni tampoco el acto de enfriar los envases lenta o rápidamente.

Se ha comprobado que, una vez más la calidad del producto enlatado permanece inalterada cuando se usa un envase con cuerpos estañados y tapas esmaltadas, con esmalte tipo $\mathrm{C}$, o latas interiormente esmaltadas.

Por otra parte, es evidente que el contacto del grano con superficies de hierro, de cobre o de bronce, y también dejar un excesivo espacio vacío en la lata, causa el obscurecimiento de la salmuera y parte de los granos desarrollan una mancha azulosa.

Cuando se agrega un 2 por ciento de azúcar a la salmuera, ya en latas, ni 
el sabor ni la calidad del producto se afectan; pero si se añade cloruro de calcio durante el proceso de escaldado, o directamente a la lata, evítase la rotura del grano, pero también se endurece a tal extremo que no puede utilizarse.

Además, se ofrecen datos y recomendaciones sobre el proceso que debe seguirse para enlatar gandures de alta calidad.

\section{LITERATURE CITED}

1. Sánchez-Nieva, F., Rodríguez, Angel J., Benero, J. R., Improved Methods of Canning Pigeonpeas, Bul. 157, Agr. Exp. Sta., Univ. P.R., 1961.

2. - U.S. Canned Food Grades; The Canning Trade Almanac, p. 106, Baltimore, Md., 1951.

3. Official Methods of Analysis, Association Official Agricultural Chemists, Washington, D. C., 8th ed. 572, 1955. 